\title{
Editorial
}

\section{Informal dynamics of economic processes}

\author{
Remarks on the potential of the informality concept
}

The aim of this special issue is to expand the concept of informality by incorporating recent approaches from institutional economics and governance theory. The concept is applied empirically to analyse economic processes in the context of mega-urban regions and global change. This introduction outlines the conceptual approach by focusing on the advancements in comparison to earlier informality paradigms. It discusses the added value of a new informality perspective for economic geography and explains how the individual papers fit in. The contributions to this special issue are based on research projects that were carried out within the Priority Programme (SPP) 1233 "Megacities - Megachallenge: The Informal Dynamics of Global Change" funded by the German Research Foundation (Deutsche Forschungsgemeinschaft), whose support of the projects is thankfully acknowledged.

\section{The shifting conceptualisations of informality over time}

The terms 'informal' and 'informality' have a connotation of inferiority in the sense of 'unofficial' or 'without form', but they can also be understood in a positive way as 'casual' with a focus on freedom of action. This simple illustration shows the ambivalent character of informality. The term informality was first used in the 1970s by the ILO (1972) and HART (1973) in several reports about the informal sector in developing countries. Their informal sector comprises all economic activities that are not organised in line with the legal, technological and managerial standards of modern sectors in developed countries. By drawing a clear line between the formal and the informal, these studies focused on those niches of the economy that (i) helped migrants in urban areas and slum dwellers to survive (survival economies), (ii) carried out illegal activities in the underground scene without official regis- tration and unnoticed by the tax administration (shadow economies), or (iii) micro enterprises without any substantial capital stock that do not produce for the markets of the formal economy (subsistence economy) (PORTES et al. 1989; CHEN/GEREFFI 1994). German-speaking human geographers used the concept of the informal sector intensively during the late 1980 s and early 1990s (c.f. ScHAMP 1989, 1993; EsCHER 1999a). A distinct structural debate emerged around the informalisation of labour during the post-Fordist transition. Formal wage labour became the leading form of labour organisation of Fordism and even spread to the economic periphery. From a Marxist point of view, this is not seen as a success of labour unions, but rather as being due to the benefits of formal labour for the capitalist system. At the same time, informal labour still persisted, for example in the form of domestic work, subsistence economy and production of petty goods. A renaissance of the informal economy was more recently caused by post-Fordism and also occurred in economic centres (KOMLOSY et al. 1997). While the Marxist tradition interpreted this shift as a coordinated attack on the organised labour class, other scholars of industrial organisation economics referred to the overall gains in efficiency and flexibility of a more informal organisation of economic systems and focused on the possibilities for prosperity that this new production paradigm implicated (PIORE/SABEL 1984).

This earlier informality concept was problematic due to its dualistic nature that implied a clear distinction, and which turned out to be less useful in practical research. SCHAMP $(1989,12)$ pointed out that the formal and the informal sectors were rather the extrema of a continuum. The heterogeneity of the informality definition made it virtually intangible in empirical studies, despite the fact that the coarse character (ESCHER 1999b) of the concept resulted in its ubiquitous application dur- 
ing its time. Finally, the focus of research on informality and the informal sector was mainly limited to poor developing countries with an emphasis on urban areas. This hindered the integration of informality in modern growth and development theories in economic geography. The dualistic character of the criteria that defined the informal sector resulted in the lack of a sound theoretical foundation of informality, which became clearly apparent in comparative studies of different countries and regions. In this context, the quote 'The informal sector is like an elephant: we may not be able to define it precisely, but we know it when we see it' is attributed to Hernando de Soto (MEAD/MoRRISSON 1996). Obviously, this fuzziness impedes the application of the concept for empirical research and policy recommendations and points out the necessity of a conceptual clarification. MEAD/MorRISSON (1996) declared that they would not use the term 'informal sector' in future studies. Frieling $(1989,74)$ stated that it was not possible to overcome the vague terminology of the research object 'informal sector', and that the term was merely understood as a residual that was inferior to the formal sector. The interpretation of informality as a residual category or something contrary to the rules is problematic in that it requires a definition of what is regular or normal. The formal-informal dichotomy of the informality literature in the 1980s and 1990s was based on formal laws defined by the dominant legal system in Europe and North America. Such an Eurocentric perspective overlooks the fact that the legal tradition of the Code Napoleon of 1804 might be less meaningful in other parts of the world. Therefore, an informality definition that is applicable in other macro-institutional environments should be based on a generalisable concept.

The recent debate surrounding informality shifted the focus away from a dichotomous definition towards an integrative framework that is embedded within current conceptual developments in economics and social science. Based on a new understanding of the state and governance, the level of practice, regulatory systems and process-related elements is targeted instead of persisting with the investigation of structural elements. The concept of informality derived from this exercise avoids a strict distinction between formality and informality, and concerns itself with the interdependence of social process and structure. This al- lows an examination of informal dynamics both within a continuum (SINDZINGRE 2007) and from a multi-dimensional perspective that focuses on the informal dynamics of institutional arrangements rather than on a static informal sector. As a result, modern approaches to informality are neither predetermined as being an inferior residual category nor restricted to developing countries, but informal practices are understood as a governance mode in their own right that is intertwined with formal institutional arrangements. Indications of such an integrative perspective can already be found in critical reviews of the informal sector by ChEng/GerefFi (1994) and Frieling (1989).

The advancement of the informality concept in economic geography is driven by the three strands of institutional approaches in economics and social science (MARTIN 2000). They have the potential to replace the older institutional tradition of the discipline that stressed the static-structural and historical-deterministic approach by Veblen (RAFIQUI 2009). Institutional arrangements for the governance of organisations and collective goods, as introduced by COASE (1937), WILLIAMSON (1975), and OsTROM (1990) form the starting point for a redefinition of informality and are central for the following explanations. New institutionalism with its central authors SCOTT (1987), DiMAGGIO (2001) and Powell (Powell/DiMaggio 1991) provides additional elements from organisational studies. The historical understanding of institutions by NORTH (1990) adds a dynamic-evolutionary perspective on institutional change. Furthermore, concepts of vulnerability and resilience as well as the sustainable livelihood approach that dominates geographical development studies allow for the integration of an institutional informality concept within the development debate.

\section{Informality in new institutional economics and organisation science}

Institutions are defined in a broad sense as a system of rules (HodGSON 2006). These rules comprise consciously created and externally enforced formal rules, for example laws, and self-enforcing, informal ones, for example traditions, norms, conventions, or customs (NORTH 1990). Additionally, New Institutional Economics (NIE) distinguishes between rules (= institutions) and actors (= organisations or 
individuals) who are interdependent. The behaviour of actors is restricted and incentivised by institutions, but actors are also involved in the creation and transformation of institutions in a co-evolutionary way. Three levels for a conceptual redefinition of informality are derived: (i) informality of the institutional environment, (ii) informality of institutional arrangements, and (iii) informality of processes within organisations. An informality concept that is informed by institutional economics is not primarily focused on the structural elements (Which transactions are carried out?), but on the underlying practices (How are transactions carried out?) and dynamic processes (What impact does co-evolution of institutional environment and arrangements have on institutional change?).

Institutional environment: The institutional environment has an informal and a formal component which are intentionally understood as interdependent in a co-evolutionary relationship by NORTH (1990), not in a dualistic, mutually exclusive way. Acceptance and enforceability of new formal institutions depends on the fit with existing informal institutions. The externally imposed adoption of rules and regulations during the transition of previously planned economies into market economies is a frequently cited example (STIGLITZ 1999; ROLAND 2000). It has been shown by De SoTO (2000) that a lack of alignment of formal rules of capitalism with informal institutions resulted in dysfunctional institutional frameworks or institutional chaos. A central question of this strand of institutional informality at the process level is whether the institutional environment is better shaped by governments or related public actors in a top-down manner, or in a self-organised bottom-up manner through unintended effects of the aggregate behaviour of individuals. Ostrom (1990) explained why one should be sceptical about leaving formation and enforcement of institutions for collective action mainly to governmental bodies, and proved it by using the example of the commons. The Austrian school of economics (HAYEK 1973) has also indicated that the aggregate order of economy and space is brought about by complex interaction of its actors. Self-organisation and emergence of the institutional environment are understood as an expression of informality.

Institutional arrangements: Institutional arrangements, i.e. contracts among economic ac- tors in a broad sense, are the central focus of the informality perspective in NIE. GUHAKHASNOBIS et al. (2006) distinguish between two levels which can be applied for the analysis of informality of institutional arrangements. At the first level, the interdependence of an institutional arrangement with its formal and informal institutional environment is described and the explanatory power of the institutional environment for the arrangement is exposed. At the second level, the structuration of the institutional arrangement itself is depicted in several dimensions, the formal and informal aspects of which are not necessarily mutually exclusive, but mostly complementary. In a multi-dimensional approach, LI (2007) defined five dimensions to characterise the formal and informal contents of institutional arrangements: formation (exogenous vs. endogenous), codification (explicit vs. implicit), enforcement (tight and strict vs. loose and flexible), power (hierarchical vs. horizontal) and personalisation (depersonalised vs. personalised). Informality thus possesses a subjective, emotional and personal character, while formality is objectively based on facts and cognition. It is important to mention that this should not result in new dichotomies, but rather in multiple dimensions that allow for continuous specification of institutional arrangements within the formality-informality nexus.

The multidimensional, non-dichotomous character of informality is illustrated by comparing the advantages of particular institutional arrangements. In most real world situations, economic activities are embedded flexibly in a dynamic and complex institutional environment. In such a situation, informality is a strategic opportunity to complement formal arrangements proactively. In close connection to NIE, contract theory (HART/MOORE 1999, 2004) has shown that most contracts are unable to comprehend completely the object that is to be regulated in a formal way due to complexity and uncertainty. Therefore, contracts remain incomplete at the time they are concluded and are specified and modified in an informal process during the contract period. This process is often socially embedded. Nevertheless, if a high level of uncertainty is connected with the institutional environment at a particular location or in a market, it might be necessary to adapt informal arrangements as a passive reaction to non-enforceable formal arrangements. 
Institutions in organisation science: Sociological institutionalism, with ScOTT (1995), DiMAgGio/Powell (1991), and in Germany MAYNTZ/SCHARPF (1995) being its main authors, looks at economic activity as a process that is embedded in a socio-institutional system or culture-specific social network. Informality is defined in this approach as interaction between individuals or groups which could be described, for example, as casual, trust-based and reciprocal. This normative-collectivist perspective adds to the rational choice institutionalism of NIE by explaining why trust is of critical importance in economic and social life and why cooperative arrangements are formed even in addition to the transaction cost argument. The aim is not to deduce the most costefficient institutional arrangement in order to reach an economic goal. In fact, embedded institutional arrangements are not just strategic means in an economic sense, but they also shape the preferences and identities of a society. Their impact is not necessarily in the form of increasing efficiency, but also in the provision of societal legitimacy of individual actions. The embeddedness perspective on informality becomes important if culture-specific aspects are introduced to explain why personal trust-based networks are chosen for economic transactions in situations where alternative governance forms are available and useful. This approach is of importance to understand the relevance of informality for interactive learning and the related processes of transforming and exchanging knowledge. There is a close link with the concept of social capital.

Research on social embeddedness of economic processes has also shown that informal networks may have a negative impact (GRANOVETTER 1973; GRABHER 1993). The starting point of this argument is the exclusiveness that is an almost necessary outcome of stable, trustbased networks and that is responsible for the desired effects of these networks. However, this feature often results in the judgement of alternative options based on the position of the actor in the network, and is no longer fair and unbiased. A lack of transparency as well as gatekeeper functions of central actors or groups in the network can be responsible for lock-ins or cronyism in the long run.

The relevance of institutional approaches for economic geography has been shown prominently by MARTIN (2000), who explained why the spatial differences of institutional environments and arrangements and their effects on the space economy are important topics for the discipline. A major argument for the spatial dimension of NIE is the fact that institutions are not equal across space, but are localised at particular points in space and are territorially bounded in their effects. Formal institutions created by the state are particularly restricted by administrative borders. However, informal or self-organised institutions also contain a spatial dimension, since they came into being due to specific local actor constellations, for example in agglomerations or local networks, and they only guide action within these spaces. SCOTT/STORPER (2003) have shown that agglomerations are advantageous due to their ability to reduce transaction costs. Based on the discussion above, it is expected that spatial differences of institutional environments lead to specific institutional arrangements in each region. This is of particular relevance if transactions are analysed that span spaces with different institutional frameworks. Furthermore, conceptual considerations and empirical applications of NIE in growth theory (ACEMOGLU et al. 2005) have revealed a major impact of institutions on differences in growth rates across countries and regions. And finally, the institutionalism in sociology gains its spatial dimension from the fact that social action is embedded in local contexts and that informal institutions, and thus actions, depend on their spatial and cultural context.

\section{Informality in the mega-urban economy}

The definition of informality that has been discussed so far is not restricted to developing countries or urban regions, as is the case with the older concept of the informal sector. However, there are arguments in favour of the fact that mega-urban regions, such as the Pearl River Delta in China or Dhaka in Bangladesh, are characterised by high levels of informality in an institutional sense. Mega-urban regions are more complex and disparate in their economic and social structures. They are closely integrated into global processes due to their economic, political and societal importance. Furthermore, rapidly growing mega-urban regions are characterised by an increasing speed and degree of institutional change. They are also highly vulnerable to economic, social and ecological shocks. Altvater (2005) identified the time 
and space compression under conditions of globalization and the rapid growth of megacities as major drivers of an informalisation in mega-urban regions, which is also visible in advanced market economies (SASSEN 1997). While the negative impacts of informalisation, for example in terms of the exclusion of the urban poor, prevail in the literature, the potentials of informality for development and competitiveness at the individual, firm and regional level, which were already put forward by DE Sото (1989), are at least equally important for the institutional approach used in this special issue. Altvater (2005) also concedes that informality enables the realisation of a bundle of political objectives such as formation of cooperatives and micro-credit organisations, support of local and regional networking, support of cooperation with universities and other public institutions, and creation of a legal framework which contains much more than the mere distribution of property rights. Thus, informality may provide the flexibility that is necessary to adapt to rapidly changing framework conditions.

By focussing particularly on urban governance, Roy (2005) has shown that the ability of public actors is insufficient to plan mega-urban regions efficiently, but that informal self-organisation of institutions by non-public actors and related informal arrangements for risk management and increased resilience play a central role. This does not imply that largescale infrastructures are not provided by the formal government, but due to the complexity of mega-urban regions and the often limited governance capability of megacities in developing countries, a complementary use of informal arrangements is expected to increase the governance efficiency.

The increasing global organisation and integration of economic activities as a central part of globalisation remains a megatrend that shapes the spatial economy (SCHÄTZL 2000). This process is characterised, among other things, by the spatial disintegration of value chains, the emergence of global production networks and an increasing division of labour based on the principle of flexible specialisation (PIORE/SABEL 1984). At the same time, shorter product life cycles require firms to remain flexible by adapting to volatile markets that are increasingly plagued by bubble-like expansions and crisis-like downturns. The underlying changes of economic systems result in a higher number of interfaces among companies, sites within multinational corporations, business services, and knowledge providers along the global value chain. The increasing complexity of interactions and flows and the necessity to span spatial, institutional and organisational distances reduces the possibility to fall back to standardised, completely formalised institutional arrangements and increases transaction costs, with informal aspects such as incremental and continuous adaptation processes during the interaction becoming more important. It is expected that traditional formalised arrangements will remain important, but that they will be complemented by informal ones in the sense of incomplete contracts. In volatile competitive environments, informality of external relations at the micro level may provide organisations with the amount of flexibility that is necessary to gain stability and competitiveness at the macro level. The strategic use of opportunity informality is suggested to increase flexibility and competitiveness and is covered by using the terms agility or agile firm organisation.

In recent years, the global economy has been characterised by far-reaching changes of formal institutional environments defined by the state at different levels which may be observed in countries and regions at different stages of development. The institutional fabric of developed countries in Western Europe and North America was adapted to the requirements of a globalised economy with further rounds of deregulation and liberalisation. Previously centrally planned economies have been involved in a fundamental transition process since the 1980 s which is still going on in countries that have chosen a gradual strategy, such as China. The integration of developing countries into global value chains and the rapid industrialisation of regions in East and Southeast Asia are a related result of globalising forces in the first round, but have also been a driver of the most recent round of globalisation.

Amidst these changes, it is particularly relevant to analyse the fit of new formal and existing informal institutions and to assess how economic actors cope with frictions of institutional systems. Since informal institutions are transformed slower than formal ones, it is very likely that self-organised institutions and institutional arrangements will be defined by the eco- 
nomic actors themselves as a substitute for missing or dysfunctional formal institutions set by the state, at least for a certain period of time during accelerated institutional change. At the same time, the transition from plan to market redefines the relationship between the state and the market as well as that among individual economic actors. Uncertainties related to this process are expected to be bridged or reduced by the emergence of hybrid institutions and arrangements. However, necessity informality induced by rapid institutional change is rather expected to be a temporary phenomenon that arises from the necessity to substitute for missing or dysfunctional formal institutions.

The six papers that were accepted for publication in this special issue specify different aspects of the institutional approach to informality and provide empirical tests and illustrations. Five papers deal with the mega-urban region of the Pearl River Delta, China, and one paper with the megacity of Dhaka, Bangladesh. Susanne Meyer deals with customer-supplier relationships and provides empirical facts that support the proposition, that an increasing amount of informality occurs due to the higher level of flexibility of production processes and the transcendence of different institutional environments by global production networks. Firms from Hong Kong use informal arrangements not only to govern transactions with local producers in the Pearl River Delta, but also with customers on the global scale. In these constellations, contractual relationships are becoming less specified and specifiable by complete contracts, and are governed by framework agreements that define the scope of the relationship and the terms of reference in general. Personal contacts are a method of identifying capable suppliers and reducing uncertainties about capabilities and conflicts of interest through personalised trust and reputation. In the low-tech sector, a competitive edge over a large number of technologically similar competitors is achieved through reliability and adaptability in terms of delivery times and product quantities with sufficient quality. In the high-tech sector, personal relations may be a method of ensuring the technological competence of the supplier. In addition, contracts are more often enforced informally using mediation or arbitration and through social power rather than using slower formal litigation, which is also more detrimental to reputations due to its publicity.
Frank Bickenbach and Wan-Hsin Liu extend the discussion about the extent and determinants of informality to a larger set of business functions. Their argument is based on the hypothesis that the availability of formal rulebased procedures increases in the course of the Chinese transition process and that informal personal governance decreases. However, the expected effects are, in general, rather weak and only significant for very few business functions. Similar to the findings of Meyer, Bickenbach and Liu conclude that informality is not a transitory phenomenon that disappears in the process of institutional transition. There is evidence that positive effects of informality and path-dependent persistence prevail.

Markus Keck, Hans-Georg Bohle and Wolfgang-Peter Zingel examine whether social processes and informal adaptation to risks result in an increasing level of resilience. Informality is defined as trust-based personal relations and a high degree of social capital. Effects are found for the micro level in the form of greater flexibility and adaptability of the actors, and at the macro level in terms of increased resilience of the urban food system as a whole.

The effects of informality and flexibility are also empirically tested by Pamela Hartmann, Daniel Schiller and Frauke Kraas, who focus on the impact of workplace quality on labour turnover and its long-term effects for upgrading processes. Labour relations are significantly transformed by the flexibilisation of the production organisation. On the one hand, highly qualified employees with long-term contracts among the core staff are expected to fulfil a large and varying range of functions with highly flexibilised working hours. On the other hand, less qualified peripheral staff are strongly affected by numerical volatility. Flexible firms organise their labour force based on the concept of the 'breathing factory' and use informal channels of employment that differ from strict formal regulations. In developing countries, informal employment is related to missing or incomplete labour contracts, low qualifications and an absence of social security entitlements. Finally, the long-term effects of highly informal labour relations for training and upgrading of the labour force are discussed. It is concluded that informality and flexibility ensure the short-term success in highly competitive markets. However, there is 
strong empirical evidence to suggest that it may not provide the preconditions in terms of absorptive capacity and skills to move beyond the low-tech, labour-intensive segments of the value chain in the long run.

Wenying Fu, Daniel Schiller and Javier Revilla Diez are explicitly looking at these upgrading processes at the firm level and potentials for the emergence of innovative milieus in the Pearl River Delta. The importance of informality for upgrading is measured by social proximity in comparison to more formal organisational proximity. Positive effects of social proximity are revealed for the implementation of a wide range of innovation activities and for coping with volatile demand. However, social proximity is mainly applied by domestic firms to acquire access to the latest technology and market information from foreign firms. Therefore, the impact on product innovation performance is still fairly small and the level of trust-based interactive learning between firms in the region remains low. This is substantiated by the fact that firms that rely on formalised organisational proximity are at least as successful with respect to innovation outputs. This paper links the institutional perspective with an evolutionary approach, since it is shown that endogenous potentials of the currently externally governed production system of the Pearl River Delta are still too weak to provide the basis for the emergence of an innovative milieu.

The global integration of economic activities and the related institutional change has resulted in a far-reaching transition of the role of the state and its relationship with economic actors. The catchwords 'new public management' and 'public-private partnership' demonstrate the increasing overlap of public and private actions that has resulted in a total withdrawal of the state or outsourcing of its activities in some areas. Complex bargaining processes among the actors involved, new participative institutional arrangements and self-organisation have thereby come into being for the definition of institutional frameworks. The increasing level of differentiation of government actions seems to result in increasingly informal arrangements between the state and private actors. Friederike Schröder and Michael Waibel position their contribution at the interface of state and economy by focusing on informality in planning processes for the restructuring of ur- ban spaces. Their case study of a development project in Guangzhou, the capital of the Guangdong province, shows that the local government reacts to the dynamic complexities of the multi-faceted restructuring process by applying innovative and flexible governance modes. Experimental policies and informal governance allowing for a certain degree of self-organisation are exclusively applied in spatially-bounded development zones. Recently, the government has made particular use of this approach in projects that aim to attract knowledge-intensive business services and a highly qualified, creative workforce.

\section{References}

Acemoglu, D./Johnson, S./Robinson, J.A. (2005): Institutions as a fundamental cause of long-run growth. In: Aghion, P./Durlauf, S.N. (Eds.): Handbook of economic growth, vol. 1A. Amsterdam, 385-472.

Altvater, E. (2005): Globalization and the informalization of the urban space. Aalborg. (Aalborg University, Development Research Series: Working Paper No. 131).

CoAsE, R.H. (1937): The nature of the firm. In: Economica, 4, 386-405.

Cheng, L./Gereffi, G. (1994): The informal economy in East Asian development. In: International Journal of Urban and Regional Research, (18)2, 194-219.

De Soto, H. (1989): The other path. The invisible revolution in the Third World. New York.

De Soto, H. (2000): The mystery of capital. Why capitalism triumphs in the West and fails everywhere else. New York.

DiMaggio, P./Powell, W.W. (1991): The new institutionalism in organizational analysis. Chicago.

DiMAggio, P. (Ed.) (2001): The twenty-first-century firm. Changing economic organization in international perspective. Princeton.

EsCHER, A. (Moderation)(1999a): Informeller Sektor in der Dritten Welt. In: Geographische Rundschau, (51)12. (Themenheft).

Escher, A. (1999b): Der Informelle Sektor in der Dritten Welt - Plädoyer für eine kritische Sicht. In: Geographische Rundschau, (51)12, 658-661.

FrIELING, H.-D. von (1989): Das Konzept des Informellen Sektors. Kritik eines Entwicklungsidealismus. in: Schamp, E.W. (Hrsg.): Der Informelle Sektor. Geographische Perspektiven eines umstrittenen Konzepts. Aachen, 169-199.

GraBHER, G. (1993): The weakness of strong ties. The lock-in of regional development in the Ruhr Area. In: Grabher, G. (Ed.): The embedded firm. On the socioeconomics of industrial networks. London, 255-277. 
Granovetter, M.S. (1973): The strength of weak ties. In: The American Journal of Sociology, (78)6, 13601380 .

Guha-Khasnobis, B./Kanbur, R./Ostrom, E. (Eds.) (2006): Linking the formal and informal economy. Concepts and Policies. Oxford. (WIDER Studies in Development Economics)

HART, K. (1973): Informal income opportunities and urban employment in Ghana. In: Journal of Modern African Studies, 11, 61-89.

Hart, O./Moore, J. (1999): Foundations of incomplete contracts. In: The Review of Economic Studies, 66, 115-138.

Hart, O./Moore, J. (2004): Agreeing now to agree later. Contracts that rule out but do not rule. Cambridge, MA. (NBER Working Paper No. 10397).

HAYEK, F. v. (1973): Law, legislation and liberty. Vol. 1: Rules and orders. London.

Hodgson, G.M. (2006): What are institutions? In: Journal of Economic Issues, 40, 1-25.

ILO (International Labour Organization)(1972): Employment, incomes and equality. A strategy for increasing productive employment in Kenya. Geneva.

Komlosy, A./Parnreiter, C./StAcher, I./Zimmermann, S. (Eds.) (1997): Ungeregelt und unterbezahlt. Der informelle Sektor in der Weltwirtschaft. Frankfurt am Main.

LI, P.P. (2007): Social tie, social capital, and social behaviour. Toward an integrative model of informal exchange. In: Asia-Pacific Journal of Management, 24, 227-246.

MARTIN, R. (2000): Institutional approaches in economic geography. In: Sheppard, E./ Barnes, T. (Eds..): A companion to economic geography. Malden, 77-94

MAYNTZ, R./ScharpF, F.W. (1995): Der Ansatz des akteurzentrierten Institutionalismus. In: Mayntz, R./ Scharpf, F.W. (Hrsg.): Steuerung und Selbstorganisation in staatsnahen Sektoren. Frankfurt am Main/New York, 39-72.

MEAD, D./Morrisson, C. (1996): The informal sector elephant. In: World Development, (24)10, 1611-1619.

NoRTH, D.C. (1990): Institutions, institutional change and economic performance. Cambridge.
Ostrom, E. (1990): Governing the commons. The evolution of institutions for collective action. New York.

Piore, M.J./SABEL, C. (1984): The second industrial divide. Possibilities for prosperity. New York.

Portes, A./CAstells, M./Benton, L. (1989): The informal economy. Studies in advanced and less developed countries. Maryland.

RAFIQUI, P.S. (2009): Evolving economic landscapes. Why new institutional economics matters for economic geography. In: Journal of Economic Geography, 9, 329353.

Roland, G. (2000): Transition and economics. Politics, markets and firms. Cambridge, MA.

Roy, A. (2005): Urban informality. Toward an epistemology of planning. In: Journal of the American Planning Association, (71)2, 147-158.

SASSEN, S. (1997): Informalization in advanced market economies. Geneva. (ILO - Issues in Development Discussion Paper 20).

SCHÄTZL, L. (2000): Wirtschaftsgeographie. Band 2: Empirie. Paderborn. (3. Aufl.)

Schamp, E.W. (Hrsg.)(1989): Der Informelle Sektor. Geographische Perspektiven eines umstrittenen Konzepts. Aachen.

Schamp, E.W. (Ed.)(1993): African small-scale industries in rural and urban environments. Challenges for development. Frankfurt am Main. (Frankfurter Wirtschafts- und Sozialgeographische Schriften 63).

SCOTt, A.J./StorPER, M. (2003): Regions, globalization, and development. In: Regional Studies, (37) 6-7, 579-593.

ScotT, W.R. (1995): Institutions and organizations. Thousand Oaks.

SINDZINGRE, A. (2007): The relevance of the concepts of formality and informality. A theoretical appraisal. In: Guha-Khasnobis, B./Kanbur, R./Ostrom, E. (Eds.): Linking the formal and informal economy. Concepts and policies. Oxford, 58-75.

Stiglitz, J. (1999): Whither reform. Ten years of the transition. Washington. (Paper prepared for the Annual World Bank Conference on Development Economics, Washington, D.C., April 28-30, 1999).

Williamson, O.E. (1975): Markets and hierarchies analysis and antitrust implications. A study in the economics of internal organization. New York. 